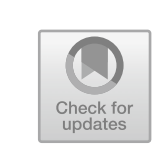

\title{
2
}

\section{Linking Long-Term Changes in Social-Ecological Systems with Development of Property Rights}

In this chapter, we examine the links between long-term changes in social-ecological systems and the development of property rights by studying self-governance, CPRs, and property rights in a Sami context, and by introducing our theoretical framework. We start with selfgovernance to describe how early modern Sami in interior northwest Fennoscandia built their own institutions for governance of natural resources. The main conclusion is that Sami by and large created their own rules for how resources should be harvested and consumed, as well as for how resources should be monitored and rules should be enforced. We use CPRs and property rights to describe how well-defined property rights were a prerequisite for people to engage in, and gain profits from, land-use regimes. For Sami in interior northwest Fennoscandia, land use centered around reindeer herding, fishing, and hunting. We conclude that their access to natural resources, and rights to use them, determined the households' economic performance and development. In the last section of this chapter, features of two frameworks are introduced. They give a background to our theoretical thinking and provide a means 
of organizing the inquiry into a set of variables to examine. We also highlight how the frameworks assist in clarifying relevant explanatory factors and how these contribute to fulfilling our aim.

\section{Self-Governance}

Research about pre- and early modern natural resource management among Sami has mainly focused on three perspectives. Up to the 1970s, the research was dominated by ethnographic accounts of pre-industrial culture, religion, tools, and traditions. ${ }^{1}$ A distinction was made between people with history and people without history. From the 1980s, scholars in archaeology and history have worked intensely to write Sami history, and over the past four decades the understanding has increased vastly. It has, among other things, shed light on the significance of natural resource management for the relations between Sami groups and nonSami groups along two intellectual lines. First, some scholars have emphasized the encounters between Sami societies and the nation-states Sweden, Denmark/Norway, and Russia, and interpreted most changes in Sami's natural resource use as responses to state interventions. ${ }^{2}$ Second, other researchers have underlined that Sami groups had agency and argue that they, by interacting with actors belonging to non-indigenous institutions, i.e., national and international trade networks, could generate and maintain a number of features considered integral to Sami society. However, similar to the first group of researchers, these scholars have argued that most changes in indigenous natural resource use were a response to external driving forces with the argument that the state "considerably undermined the foundation for autonomous Sámi social systems." 3 One of the most intense research discussions when it comes to pre-modern Sami land use revolves around the question of when, why,

\footnotetext{
${ }^{1}$ Hansen and Olsen (2014, p. 2).

${ }^{2}$ Hood (2015) and Lundmark (2006).

${ }^{3}$ Hansen and Olsen (2014, p. 229).
} 
and how this society transitioned from hunting and fishing to reindeer herding, and the latter has been the main focus for scholars. ${ }^{4}$

The last four decades of historic and archaeological research has well illustrated how Sami lost many of their rights to natural resources due to actions of expanding nation-states. However, we contribute a previously rather neglected self-governance perspective to the study of early modern Sami land use that clarifies how users in interior northwest Fennoscandia, notwithstanding an ongoing colonial project, could build their own institutions to govern use of natural resources. We also contribute readings of how these self-governing institutions co-evolved with the transforming Sami economy. The study of indigenous users' self-governance, or selforganization, is important for several reasons. As pointed to in Chapter 1, it is significant to look beyond "the suffering subject" if we want to understand how indigenous groups governed natural resources. ${ }^{5}$

Historical studies of how indigenous people have built institutions for natural resource management and how they have changed over time are still rare. Knowledge about how Sami created rules for governance can probably bring clarity to the organization of land use among other indigenous groups. Moreover, it is not possible to understand how the household economy changed without considering the rules that were created by the users and how the users were active players in building and changing these rules. As we will show throughout this book, we argue that early modern indigenous users in interior northwest Fennoscandia, by and large, created their own property rights connected to resource use in a self-governing context. ${ }^{6}$ Institutions - rules and norms-were not only necessary to determine who had the right to use land and water, they were instrumental in maintaining equity and ensuring household subsistence.

In the sixteenth and early seventeenth centuries, the Swedish government's interest in interior northwest Fennoscandia increased. Initially, the interest was driven by geopolitical motives, such as the power struggle over international maritime trade in the Arctic Ocean, and by the state's

\footnotetext{
4 Sommerseth (2011) and Bergman et al. (2013).

${ }^{5}$ Robbins (2013, p. 447).

${ }^{6}$ Ostrom (2005, pp. 255-258).
} 
desire to control Sami's fur trade and taxation. ${ }^{7}$ The latter was both a means of getting revenues and an attempt to legitimize the borders of the Swedish realm. Moreover, in the seventeenth and eighteenth centuries, the government started to promote mining enterprises and agrarian colonization in interior northern Sweden. It was not until the nineteenth century that political ambitions gained pace as the agricultural colonization grew and started to have a heavy impact on the landscape. ${ }^{8}$ In this process, the indigenous population was steadily pushed aside and their rights to land and culture gradually diminished. Nonetheless, until the nineteenth century, Sami's decisions about land use were mostly governed through internal processes. In the early modern period, by and large, Sami created their own institutions for governance and developed their own property rights connected to resource use, such as fishing, hunting, and reindeer herding. External factors, such as changing trade patterns and new government policies, certainly played a role in the Sami economy and could be interpreted as pieces in an internal decision-making puzzle regarding natural resource use.

In a self-governance context, rules about how resources should be harvested and consumed, as well as rules about monitoring and enforcement, are usually developed by the users themselves.? During the eighteenth century, the decisions regarding the right to use natural resources were often negotiated in the local court, and by studying court transcripts it is possible to understand how users were involved in creating policy for land use. We return to this in Chapter 3, where we explain why the local court was an important collective-choice arena. The early modern Swedish government was more or less unfamiliar with Sami land-use practices, and even less familiar with the details of users' decision-making. It could not control the economy with any accuracy. The asymmetry of information between government and local users is why a self-governance perspective could deepen the understanding of

\footnotetext{
7 Göthe (1929, pp. 41-62), Hansen and Olsen (2014, pp. 229-231, 257-262) and Wallerström (2018, pp. 30-34).

${ }^{8}$ Brännlund and Axelsson (2011) and Bylund (1956).

${ }^{9}$ Definition of self-governance is "the capacity of communities to organize themselves so they can actively participate in all (or at least the most important) decision processes relating to their own governance" (McGinnis 2011a, p. 171; see also Ostrom 2005).
} 
early modern Sami economy and culture. James Scott argues, on a global level, that a number of difficulties "placed sharp limits on the reach of even the most ambitious states" until the early nineteenth century. ${ }^{10}$

We analyze early modern Sami natural resource use from a selfgovernance perspective from 1550 to around 1780. The starting point for the study was chosen for two main reasons. First, around 1550, Sami households in interior northwest Fennoscandia relied to a large degree on fishing and hunting, while large-scale reindeer herding had not yet developed. This changed rapidly, and at the end of the eighteenth century, large-scale reindeer herding, or reindeer pastoralism, had become the backbone of the economy for many households. Hence, by studying this period it is possible to investigate how the changes in the economy impacted institutions for governance. Second, the earliest systematically collected written sources, in the form of tax records and trade lists, originate from around $1550 .{ }^{11}$ These source materials make it possible to systematically retrieve information about the household economy.

Similarly, there are two main reasons behind why we chose to end the study period around 1780. First, the local court, where many user conflicts over natural resources were settled, changed procedures at the end of the eighteenth century and engaged local Sami lay-judges (see Chapter 3) to a much lesser extent. The number of sedentary settlers had by then increased and it had impacted the court's decision-making considerably. ${ }^{12}$ More importantly, however, around this time proceedings concerning land use were moved from the local court to the County Administrative Board, directly under the state government in Stockholm. ${ }^{13}$ Hence, Sami users lost direct influence over the court proceedings and were effectively excluded from participation in the settlement of strategic land-use issues.

\footnotetext{
10 Scott (2009, pp. 3-4).

11 Göthe (1929), Hultblad (1968), and Lundmark (1982).

12 Arell (1977).

13 Lundmark (2006, pp. 108-118).
} 


\section{Common-Pool Resources and Property Rights}

Reindeer herding, fishing, hunting, and gathering are activities that imply humans interacting with nature. In order to catch or trap animals, fish, or manage tame reindeer herds, users must have access to land and water. Hence, these activities can be analyzed as uses of CPRs. What characterizes a CPR is that it is difficult, but not impossible, to exclude other users and that the catch or harvest is subtractable. ${ }^{14}$ Once an animal or fish is caught, it is not possible for someone else to use or catch it, and there is potential for overuse. Overuse means, for example, that the grazing resources might be impaired if an area is grazed or trampled by too many reindeer. A robust human use of land and water requires institutions with rules that can control users' access rights in different ways. These rules might stipulate who has access, when someone has access, withdrawal amounts, punishments for violations of rules, etc. and are a means to avoid collective-action problems, such as free riding. ${ }^{15}$

Defined property rights were a prerequisite for early modern Sami to engage in reindeer herding, fishing, and hunting, and to use other natural resources, such as plants and berries. In that sense, property rights determined the group's economic performance and development trajectory, and different parties were likely to control different attributes of a resource because of their respective comparative advantages. ${ }^{16}$ An economic property right could be described as "the ability to freely exercise a choice over a good or service." ${ }^{17}$ This right could be de jure or de facto, based on customary relationships, and exist with or without government enforcements. ${ }^{18}$ De facto and de jure property rights can overlap, and a non-state-based property system recognized by all parties involved is de jure. ${ }^{19}$ Property rights cannot completely be specified and

\footnotetext{
14 Ostrom (1990, p. 90) and Ostrom (2005, pp. 258-270).

15 Ostrom (1990, 2005).

16 Lueck (1989).

17 Allen (1999, p. 898).

18 Ellickson (1991).

19 Cole (2015).
} 
strictly defined; there will always be some ambiguity. ${ }^{20}$ Property rights are a "bundle of rights" that gives both rights and duties. ${ }^{21}$

Research about management of CPRs has often focused on local users' ability to build their own institutions for governance. ${ }^{22}$ Property rights was not only a way to secure and designate harvest; it was also a means to create social justice. However, when it comes to Sami land use, selfgovernance has been discussed mostly in relation to present-day reindeer husbandry, ${ }^{23}$ not so much in an early modern Sami context. ${ }^{24}$ The exceptions are two early contributions by Ivar Bjørklund regarding pastoralism and fishing in northern Norway. However, in recent years a few attempts have been made. Gudrun Norstedt's dissertation is titled $A$ land of one's own, implying that users had a high degree self-determination, and Bertil Marklund, also in a dissertation, views a Sami village, with its resource in the forest region of Ume lappmark, as its own CPR. ${ }^{25}$

Much of the previous research on Sami's land rights in interior northern Sweden has centered on the institution of skatteland, a term known since the mid-seventeenth century as the land equivalent that a Sami paid tax for. ${ }^{26}$ Earlier research has assumed that these lands represented an older organization, predating their first appearance in the sources, and that they made up the land that a household (or a small group of households) had exclusive rights to use. ${ }^{27}$ Other scholars do not perceive skatteland as originally Sami, but rather as the result of the Swedish government's desire to organize taxing by connecting all Sami to specific places. $^{28}$ Regardless, in the mid-seventeenth century, skatteland

20 Penner (1996).

${ }^{21}$ Hohfeld (1913).

22 Gibson et al. (2005).

23 Marin and Bjørklund (2015) and Riseth (2004).

${ }^{24}$ Bjørklund (1990, 1991).

25 Norstedt (2018, p. 28) and Marklund (2015, pp. 34-38).

${ }^{26}$ Holmbäck (1922), Hultblnd (1968), Arell (1977), Korpijaakko-Labba (1994), Lundmark (2006) and N-J Päiviö (2011).

27 Holmbäck (1922, pp. 10-11).

${ }^{28}$ Hansen and Olsen (2014, pp. 287-289). Hansen and Olsen argue that skatteland is connected to Karl IX's tax reform in 1602, which "shows a strong will to regulate and create stability in the Sámi's land usage" and concludes that "there is good reason to ask whether the influence from Swedish administrative practice might in fact have been decisive in these matters 
represented a resource area that was used by individual Sami households. Furthermore, legal scholars have argued that the government gave the same rights to the holders of skatteland as it gave to skattebönder (freeholding peasants) in the rest of the country during the seventeenth and eighteenth centuries. ${ }^{29}$ But while freeholding peasants gained stronger property rights in the nineteenth century, holders of skatteland gradually lost their rights and came closer to holding the same rights as Swedish kronobönder (crown tenants).

The focus on the development of skatteland has, to a large degree, shadowed the larger context of how Sami property rights developed in the seventeenth and eighteenth centuries. Property rights has rarely been recognized as being intricately connected to customary practices that often differentiated between natural resources. Also, early modern Swedish peasants, both freeholders and crown tenants, had different property rights to different resources, implicating how and when a specific resource could be used. ${ }^{30}$ When analyzing early modern Sami property rights and land use, it is therefore reasonable to assume that their rights had also developed in accordance with their use of natural resources. Scholars have interpreted almost every change in skatteland as the result of the Swedish government's attempt to erode Sami property rights. ${ }^{31}$ Although it probably is an accurate interpretation for the nineteenth century, it is too one-dimensional to explain why and how Sami land use changed in the preceding centuries. In Chapters 5-8, we clarify the details of Sami land use and highlight the diversity of Sami property regimes and how they came to change.

Property systems are usually divided into four basic regimes: state, private, common, and non-property. ${ }^{32}$ In theoretical models, pastoralist systems are usually defined as common-property regimes. Robert Netting

[creating skatteland]." However, it is important to distinguish between the early modern state's ambition and what they actually could do to steer the Sami economy on the ground.

29 Korpijaakko-Labba (1994) and N.-J. Päiviö (2011).

30 Dahlman (1980) and J. Larsson (2014).

${ }^{31}$ Most pronounced by Lennart Lundmark (2006) in his book Samernas skatteland that gives an overview of the development through 300 years.

32 Bromley (1991). 
identified five key variables that he considered most important in differentiating common-property rights from individual rights to land, based on land use: common property is more likely to develop and be sustained if (1) the value of production per unit area is low, (2) the frequency and dependability of use or yield is low, (3) the possibility of improvement or intensification is low, (4) the area required for effective use is large, and (5) the labor- and capital-investment group is large. ${ }^{33}$ Although these variables were developed in an agricultural context, they are applicable in a Sami land use context as well. In an economy where many users became more dependent on large-scale reindeer herding, it is likely that common property would benefit these users. It would enable seasonal movements over long distances in search for available grazing. Previous research about Sami use of natural resources has mostly overlooked what role self-governance played in the development of property rights, especially common property.

Problems with the conventional property regimes are that they do not fit many real-world circumstances and policy problems are complex. ${ }^{34}$ As pointed out above, property gives both rights and duties. In most private, state, and common-property regimes there are restrictions, or circumscriptions, for what an owner can actually do with his or her property. In an early modern indigenous setting, the components included in the right to use resources are even more elusive. For the users, it was important to be able to take advantage of resources that were essential for household members' well-being, and the rights regulating their use were often well-defined from their perspective, although they might not be straightforwardly comparable to present-day understandings of rights. Consequently, we use the terms right and access interchangeably as the ability to legally derive benefits that do not presuppose property. ${ }^{35} \mathrm{We}$ want to understand how land and water were used, how users had access to resources, and how rights to access were created and changed. Users invest time and energy to make a difference in outcome. Hence, it is important to discuss how decisions were made during our study period

\footnotetext{
33 Netting (1976).

34 Cole (2002, p. 6) and Ostrom (2005, p. 256).

35 Ribot and Peluso (2003).
} 
regarding the right to fish, hunt, and use grazing land for reindeer and who were involved in these discussions and decisions. Beginning with discussions about who had legal property rights is to start from the wrong end. The Swedish state has regarded itself as the legal owner of the land, ${ }^{36}$ but as we will show, they were quite clueless about how Sami households' economy came together, how Sami managed land and water, and which users had rights to which resources. Even if there had been tensions between the state and the indigenous population already in the mid-seventeenth century, particularly regarding mining (see Chapter 4), the notion that all land in the Swedish lappmark was state owned actually started in the 1680s but not universally manifested until the nineteenth century. $^{37}$

Before we present the framework, we must point out that commonpool resources (CPRs) and common-property regimes are not synonymous. A CPR is a type of good, or resource, from which it is difficult to exclude people and where one user's harvest depletes it for other users. ${ }^{38}$ CPRs relate to the physical qualities of the resource. A common-property regime is an institutional construction where groups of individuals share private rights and duties in relation to a particular resource. ${ }^{39}$ To manage the resource, cooperation between individuals who share rights (commoners) are necessary. A common-property regime is thus a way to manage a CPR, although other property regimes are also possible: state and private. They might even be non-property or res nullius. Before the movement to enclose properties, and similar movements, where one of the goals was to shift common property to private or state property, many forests, pastures, and fisheries around the globe were owned or managed by commoners. Since the mid-eighteenth century, starting in Europe and spreading around the world during the nineteenth and

\footnotetext{
36 Lundmark (2006).

37 Holmbäck (1922, pp. 44-68) and Lundmark (2006, pp. 15-18).

38 Ostrom (2005).

39 Bromley (1990), McKean (1996), and Ostrom and Hess (2010); Swallow and Bromley (1995, p. 100) "consider a common property regime to be a set of institutional arrangements that define the conditions of access to, and control over, a range of benefits arising from collectively-used natural resources."
} 
twentieth centuries, more and more common property was dissolved and transformed to private property or state property.

\section{Connecting Variables for Policy Decisions}

Reindeer herding, fishing, and hunting all entail human interaction with nature and can therefore be considered parts of social-ecological systems. Since they require access to land or water, they also entail use of CPRs. Two commonly used frameworks to analyze CPRs are Institutional Analysis and Development (IAD) and the later Social-Ecological Systems (SES). ${ }^{40}$ Both belong to what has been labeled the Bloomington School of Political Economy with Nobel Laureate Elinor Ostrom as the central creator. ${ }^{41}$ However, the development of the original frameworks was a collaborative work with numerous people involved and it is still an ongoing process. This is particularly true for the SES framework that was launched in the fall of $2007 .{ }^{42}$

The emphasis of these frameworks is on the actors' ability to create policy when they manage natural recourses and when they build institutions for governing natural resources. Such approaches have been applied extensively, especially in analyses of self-governing communities, and they correspond very well with our inquiry, which sets out from questions to do with, for example, self-governance, ecology, natural resource management (reindeer herding, fishing, and hunting), property rights, and social justice. The basic idea of the framework is that all decisions in policy processes have outcomes and these outcomes will be evaluated and lead to changes in any stage of the process, including the exogenous variables, or contextual factors, which in turn make it necessary for the users to reevaluate their policies. The reevaluation will thus result in new policy decisions, new outcomes, and new evaluations in a continuous process. At the core of the framework is the action situation where

\footnotetext{
40 Kiser and Ostrom (1982), Ostrom et al. (1993), Ostrom (2005, 2009), and McGinnis and Ostrom (2014).

41 Aligică (2014).

42 Ostrom (2007, 2009) and McGinnis and Ostrom (2014).
} 


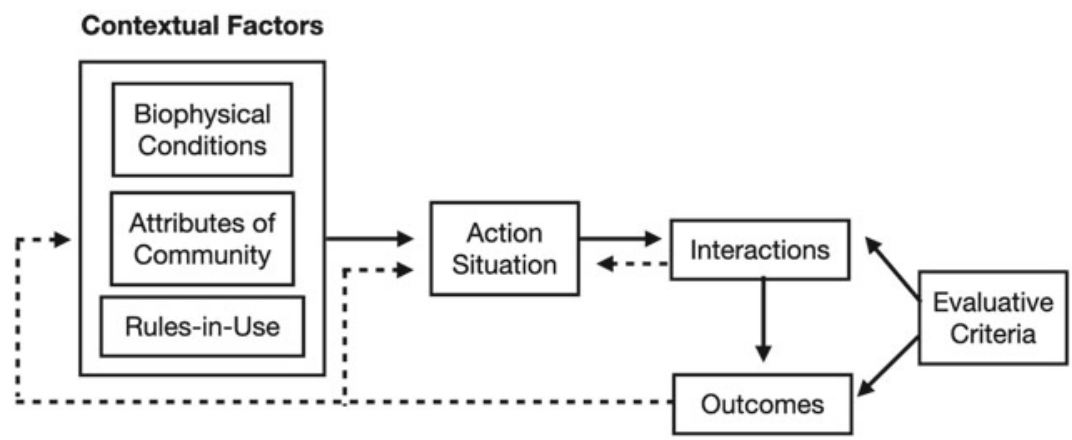

Fig. 2.1 Institutional Analysis and Development (IAD) framework (Source Ostrom [2010, p. 646], with permission)

actors are in positions to make choices among available options that affect the outcome. The "action situation" is where policy decisions are made and new institutions are created. However, not all institutions that impact a policy decision are created by the users, some might come with national legislation and others are part of older policy decisions. These will then be part of the exogenous variables that impact the action situation (Fig. 2.1).

From our point of view, the strength of the IAD framework is threefold: first it is process oriented, second it allows for interdisciplinary research tools that recognize complexity, and third, it makes it possible to investigate the process by which institutions emerge and change over time. Critics of the framework pointed out that IAD pays too little attention to the diversity and complexity of the natural systems. ${ }^{43}$ So, in response, the SES framework was developed to analyze closely coupled social-ecological systems and to identify and analyze the relationships between multiple levels of these complex systems. In order to do so the exogenous variables had to be expanded, and biophysical conditions in the IAD became the two first-tier variables, Resource system and Resource units in SES. ${ }^{44}$ The exogenous variables Attributes of the

43 Cole et al. (2019) give a short and useful introduction to the two frameworks and provide the most important references to the development of them. For an introduction to IAD, see McGinnis (2011a) and Ostrom (2010).

44 Ostrom (2007, 2009). 
community and Rules-in-use in the IAD framework are almost identical to the first-tier variables Actors and Governing system in SES. Compared to IAD, the SES framework is more formalized, and the first-tier variables are divisible into second-tier and third-tier variables that enable more fine-grained analyses of social and ecological conditions. Criticism of SES has been that scholars can present long lists of variables that may impact the outcome, and that the SES is too static. Cole, Epstein, and McGinnis summarized the problem as "scholars are left to choose between a finely-detailed but ultimately static analysis with the SES framework or a more dynamic but underspecified analysis with the IAD framework," and showed how the two frameworks can be combined. ${ }^{45}$

Both frameworks are centered around actors who make decisions that impact the outcome. We appreciate particularly that the IAD framework recognizes the dynamics of the action situation, and has an articulated feedback loop. Since we have followed users from mid-sixteenth century to the end of the eighteenth century with the ambition to understand how changes in natural resource use impacted Sami society, this dynamic has been essential. The expansion of the biophysical conditions into Resource system and Resource units in the SES has also been useful for our purposes, since the natural conditions were essential for the performance of the system. The labels for the other two exogenous variables are Actors and Governing system. In an early version of the SES framework, the first-tier Actors were called Users. However, it was later changed to Actors since the resource is not restricted solely to the users but can include a third party. ${ }^{46}$ In our case, non-Sami tradesmen and state judges would be examples of Actors who are not synonymous to users. The SES framework also offers opportunities to apply second-tier variables. These allow us to dig deeper into the underlying factors that were important for the development of natural resource management in interior northwest Fennoscandia. Even though there has been one attempt to combine the two frameworks, we stuck with the SES framework. Both frameworks have the action situation at the core which potentially gives the SES a

45 Cole et al. (2019, p. 250).

46 McGinnis and Ostrom (2014). 
Social, Economic, and Political Settings(S)

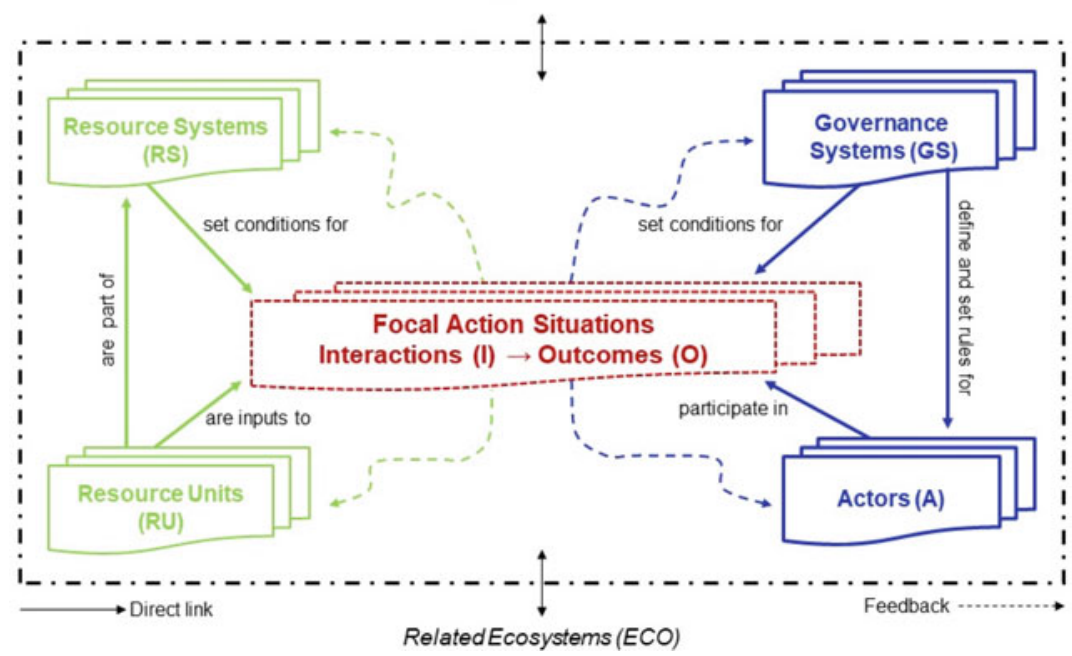

Fig. 2.2 Social-Ecological System (SES) framework with multiple first-tier components (Source Adapted from McGinnis and Ostrom [2014, Fig. 2] with permission)

"deeply dynamic orientation." ${ }^{77}$ The problem in earlier research is that this dynamic orientation was not used much (Fig. 2.2).

Rules about natural resource management can be established at three levels. ${ }^{48}$ There are three types (levels) of action situations. ${ }^{49}$ Rules on one level are nested into second-level rules that define how the first set of rules can be changed. The first level is the day-to-day, operational level where users have to make decisions about where to graze reindeer, hunt or fish, what gear to use, who is going to participate, etc. These rules can be changed quite rapidly. In an early modern Sami context, rules on this level are often hard for us today to retrieve at the household level due to lack of sources. However, the accounts we have used as sources provide some of this information, as do the court rulings. At

\footnotetext{
47 Cole et al. (2019, p. 250).

48 Ostrom (2005, pp. 58-62).

49 Cole et al. (2019, p. 246).
} 
the second, collective-choice level, rules have to be established to determine who has the right to hunt, fish, graze reindeer, or pick berries, where they can do these activities, how to do them, and sometimes when to do them. Thus, they regulate access. These rules change at a slower pace. In an early modern Sami context, the rules on this level were often made by small user groups within a Sami village, siidas, ${ }^{50}$ or at the village level. Again, it is hard for us today to retrieve information about the decision-making process. However, when users contested or violated rules, and the matter could not be resolved within the siida or village, it could be taken to the local court, which was a trusted arena for solving conflicts. Most of the court rulings from these proceedings are preserved in writing, and tell a lot about how local Sami communities treated questions that concerned users' access to land and water and who could use them. The detailed descriptions found in many court rulings also provide evidence of which gears were used, which prey were hunted, who tended and milked reindeer, who participated in fishing, etc. ${ }^{51}$ Hence, they offer plenty of information about the first level, operational rules. At the third, constitutional, level, rules are established regarding who has the right to participate in the collective-choice decisions. We touch upon this level only when we describe the function of the local court; for example, who had the right to become a lay-judge, and how they could influence court proceedings. The first two levels give sufficient information to understand and interpret the development of rules concerning early modern Sami natural resource management. To understand why the self-governance structure of Sami decision-making began to diminish at the end of the eighteenth century, one has to take the constitutional level into consideration, and carefully consider how and why Sami were deprived of participation in collective-choice arenas. ${ }^{52}$

The IAD and SES frameworks have mostly been used by social scientists in situations inspired by game theory, where it is possible to control many of the factors involved. When the frameworks are applied in a historical setting, the circumstances that determine the outcome are

\footnotetext{
50 The siida concept, and its different interpretations, is further elaborated in Chapter 3.

51 Larsson (2016) and Larsson and Päiviö Sjaunja (2020).

52 Lundmark (2006, pp. 108-118), N.-J. Päiviö (2011), and Lantto (2010).
} 
often much harder to retrieve due to lack of sources. It is more so in an indigenous setting where sources are especially scarce. Therefore, we cannot fully understand who participated in the actions that led to policy changes, and most situations will probably remain forever hidden. Another difficulty is that the time span comprises more than 200 years of development and changes. In a real-world setting, there is never only one action situation on any of the levels. Instead, the outcome of an action situation is determined by the outcome of preceding actions, and by decisions made on other, adjacent levels. A network of adjacent action situations is "when outcomes generated in one action situation help determine the rules under which interactions occur within the other action situation." ${ }^{53}$ Hence, since there are multiple action situations, we must treat them as a process. In a historical setting, it is not possible to wholly grasp all the details that were involved when rules were created and changed in practice. For us, the action situation is more like a figure of thought that can help elucidate how natural resource management came to develop, and the role of local users in that development in an early modern Sami context.

As historians, we only have some of the pieces of the puzzle of how indigenous users formed institutions for governance, and of the motivation behind rules and norms. Notwithstanding the difficulties explained earlier, the SES framework has helped us to dig deeper into early modern Sami self-governance. The framework provides a means of organizing an inquiry into a set of variables to examine. It has assisted in clarifying relevant explanatory factors. Further, it has helped us to recognize that there were actors in certain positions who made decisions about management, and that these decisions had an impact on the outcomes of the systems. We have analyzed these outcomes as both a social performance measure (e.g., efficiency, equity, sustainability) and an ecological performance measure (e.g., overharvest, biodiversity, sustainability). ${ }^{54}$ The decisions were evaluated and led to changes in exogenous variables and to new decisions.

53 McGinnis (2011b, p. 52).

${ }^{54}$ McGinnis and Ostrom (2014, Table 1). 
Our purpose is to show how indigenous users, through selfgovernance, negotiated and developed rules for natural resource management. The SES framework per se was not the focal point of our analyses; we saw it more as a categorization that helped us structure our thinking about indigenous self-governance. For reasons presented above, it is impossible to fully understand every aspect of early modern Sami land use. The framework is very useful in giving us keys to how changes in rules for management of natural resources can be understood. Nonetheless, scarcity of sources and the study's time span make it hard to apply the framework to its full extent. Hence, we will not put up the investigations as a chart where all parts of the framework will be filled out. We used it as a guide for conceptualizing our thinking.

As pointed out in the first part of this chapter, the local management of natural resources is tightly connected to its context. In the SES framework, local management and its context are related to social, economic, and political systems. New trade patterns and government policies certainly played important roles in influencing early modern Sami economy. Sami culture is shaped by its relations to neighbors and, from the sixteenth century, also relations to strong nation-states. In Chapter 4, we present these contextual circumstances and place the area of investigation in a broader context.

\section{References}

Aligică, Paul Dragoș. 2014. Institutional diversity and political economy: The Ostroms and beyond. Oxford, UK: Oxford University Press.

Allen, Douglas W. 1999. Transaction costs. In Encyclopedia of law and economics, ed. Boudewijn Bouckaert and Gerrit De Geest, 893-926. Vol. 1. Chelthenham, UK: Edward Elgar Press.

Arell, Nils. 1977. Rennomadismen i Torne lappmark: markanvändning under kolonisationsepoken i fr.a. Enontekis socken. $\mathrm{PhD}$ diss. Umeå, Sweden: Skytteanska samfundet. http://www.diva-portal.org/smash/record. jsf?pid=diva2\%3A616377\&dswid=6098.

Bergman, Ingela, Olle Zachrisson, and Lars Liedgren. 2013. From hunting to herding: Land use, ecosystem processes, and social transformation among 
Sami ad 800-1500. Arctic Antrophology 50 (2): 25-39. https://doi.org/10. 3368/aa.50.2.25.

Bjørklund, Ivar. 1990. Sámi reindeer pastoralism as an indigenous resource management system in northern Norway. Development and Change 12: 7586. https://doi.org/10.1111/j.1467-7660.1990.tb00368.x.

Bjørklund, Ivar. 1991. Property in common, common property or private property. North Atlantic Studies 3 (1): 41-45.

Brännlund, Isabelle, and Per Axelsson. 2011. Reindeer management during the colonization of Sami lands. Global Environmental Change 21: 1095-1105. https://doi.org/10.1016/j.gloenvcha.2011.03.005.

Bromley, Daniel W. 1991. Environment and economy, property rights and public policy. Oxford, UK: Blackwell.

Bylund, Erik. 1956. Koloniseringen av Pite lappmark t.o.m. år 1867. PhD diss., Uppsala University.

Cole, Daniel H. 2002. Pollution and property: Comparing ownership institutions for environmental protection. Cambridge, UK: Cambridge University Press.

Cole, Daniel H. 2015. 'Economic property rights' as 'nonsense upon stilts': A comment on Hodgson. Journal of Institutional Economics 11: 725-730. https://doi.org/10.1017/S174413741500020X.

Cole, Daniel H., Graham Epstein, and Michael D. McGinnis. 2019. The utility of combining the IAD and SES frameworks. International Journal of the Commons 13(1):244-275. https://doi.org/10.18352/ijc.864.

Dahlman, Carl J. 1980. The open field system and beyond. Cambridge, UK: Cambridge University Press.

Ellickson, Robert C. 1991. Order without law: How neighbors settle disputes. Cambridge, MA: Harvard University Press.

Gibson, Clark C., John T. Williams, and Elinor Ostrom. 2005. Local enforcement and better forests. World Development 33: 273-284. https://doi.org/ 10.1016/j.worlddev.2004.07.013.

Göthe Gustaf. 1929. Om Umeå lappmarks svenska kolonisation: från mitten av 1500-talet till omkr. 1750. PhD diss., Stockholm University.

Hansen, Lars Ivar, and Bjørnar Olsen. 2014. Hunters in transition: an outline of early Sámi history. Leiden, the Netherlands: Brill.

Hohfeld, Wesley Newcomb. 1913. Some fundamental legal conceptions as applied in judicial reasoning. The Yale Law Journal 23 (1): 16-59. http:// www.jstor.org/stable/785533.

Holmbäck, Åke. 1922. Om lappskattelandsinstitutet och dess historiska utveckling. Stockholm: Statens offentliga utredningar. 
Hood, Bryan C. 2015. Framing Sámi entanglement in early modern colonial processes. Arctic Anthropology 52 (2): 37-56. https://doi.org/10.3368/aa.52. 2.37 .

Hultblad, Filip. 1968. Övergång från nomadism till agrar bosättning i Jokkmokks socken. PhD diss. Uppsala University.

Kiser, Larry L., and Elinor Ostrom. 1982. The three worlds of action: A metatheoretical synthesis of institutional approaches. In Strategies of political inquiry, ed. Elinor Ostrom, 179-222. Beverly Hills, CA: Sage.

Korpijaakko-Labba, Kaisa. 1994. Om samernas rättsliga ställning $i$ SverigeFinland. En rättshistorisk utredning av markanvändningsförhållanden och -rättigheter $i$ Västerbottens lappmark före mitten av 1700-talet. Helsinki: Juristförbundets förlag.

Lantto, Patrik. 2010. Borders, citizenship and change. Citizenship Studies 14: 543-556. https://doi.org/10.1080/13621025.2010.506709.

Larsson, Jesper. 2014. Boundaries and property rights: The transformation of a common-pool resource. The Agricultural History Review 62 (1): 40-60.

Larsson, Jesper. 2016. Conflict-resolution mechanisms maintaining an agricultural system: early modern local courts as an arena for solving collectiveaction problems within Scandinavian Civil Law. International Journal of the Commons 10 (2): 1100-1118. https://doi.org/10.18352/ijc.666.

Larsson, Jesper, and Eva-Lotta Päiviö Sjaunja. 2020. Early modern reindeer husbandry, Sami economy, and grazing rights. International Journal of the Commons 14 (1): 91-107. https://doi.org/10.5334/ijc.965.

Lueck, Dean. 1989. The economic nature of wildlife law. Journal of Legal Studies 18: 291-324. https://doi.org/10.1086/468149.

Lundmark, Lennart. 1982. Uppbörd, utarmning, utveckling. Det samiska fångstsamhällets övergång till rennomadism i Lule lappmark. PhD diss.: Umeå University.

Lundmark, Lennart. 2006. Samernas skatteland i Norr- och Västerbotten under 300 år. Stockholm: Institutet för Rättshistorisk Forskning.

Marin, Andrei, and Ivar Bjørklund. 2015. A tragedy of errors? International Journal of the Commons 9: 19-40. https://doi.org/10.18352/ijc.586.

Marklund, Bertil. 2015. Det milsvida folket. Skogssamernas samhälle $i$ omvandling, 1650-1800. PhD diss., Umeå University.

McGinnis, Michael D. 2011a. An introduction to IAD and the language of the Ostrom Workshop. Policy Studies Journal 39: 169-183. https://doi.org/ 10.1111/j.1541-0072.2010.00401.x. 
McGinnis, Michael D. 2011b. Networks of adjacent action situations in polycentric governance. Policy Studies Journal 39 (1): 51-78. https://doi.org/10. 1111/j.1541-0072.2010.00396.x.

McGinnis, Michael D., and Elinor Ostrom. 2014. Social-ecological system framework. Ecology and Society 19 (2): 30. https://doi.org/10.5751/ES06387-190230.

McKean, Margaret A. 1996. Common property: What is it, what is it good for, and what makes it work? Conference paper delivered at International Conference on Chinese Rural Collectives and Voluntary Organizations: Between State Organization and Private Interest. http://hdl.handle.net/ $10535 / 5330$.

Netting, Robert McC. 1976. What alpine peasants have in common. Human Ecology 4 (2): 135-146. https://doi.org/10.1007/BF01531217.

Norstedt, Gudrun. 2018. A land of one's own. PhD diss., Swedish University of Agricultural Sciences, Umeå. https://pub.epsilon.slu.se/15451/1/nor stedt_g_180502.pdf.

Ostrom, Elinor. 1990. Governing the commons, the evolution of institutions for collective action. Cambridge, UK: Cambridge University Press.

Ostrom, Elinor. 2005. Understanding institutional diversity. Princeton, NJ: Princeton University Press.

Ostrom, Elinor. 2007. A diagnostic approach for going beyond panaceas. Proceedings of the National Academy of Sciences of the United States of America 104 (39): 15181-15187. https://doi.org/10.1073/pnas.0702288104.

Ostrom, Elinor. 2009. A general framework for analyzing sustainability of social-ecological systems. Science 325: 419-422.

Ostrom, Elinor. 2010. Beyond markets and states. American Economic Review 100: 641-672. https://doi.org/10.1257/aer.100.3.641.

Ostrom, Elinor, and Charlotte Hess. 2010. Private and common property rights. In Property law and economics, ed. Boudewijn Bouckaert, chapter 4. Cheltenham, UK, Edward Elgar.

Ostrom, Elinor, Roy Gardner, and James Walker. 1993. Rules, games, and common-pool resources. Ann Arbor: University of Michigan Press.

Päiviö, Nils-Johan. 2011. Från skattemannarätt till nyttjanderätt. en rättshistorisk studie av utvecklingen av samernas rättigheter från slutet 1500-talet till,. 1886. ars renbeteslag. PhD diss.: Uppsala University.

Penner, James E. 1996. The "bundle of rights" picture of property. UCLA Law Review 43: 711.

Ribot, Jesse C., and Nancy Lee Peluso. 2003. A theory of access. Rural Sociology 68 (2): 153-181. https://doi.org/10.1111/j.1549-0831.2003.tb00133.x. 
Riseth, Jan Åge. 2004. Sami reindeer management in Norway. In Indigenous peoples, ed. Svein Jentoft, Henry Minde, and Ragnar Nilsen, 229-247. Chicago, IL: University of Chicago Press.

Robbins, Joel. 2013. Beyond the suffering subject: Toward an anthropology of the good. Journal of the Royal Anthropological Institute 19 (3): 447-462. https://doi.org/10.1111/1467-9655.12044.

Scott, James C. 2009. The art of not being governed. New Haven, CT: Yale University Press.

Sommerseth, Ingrid. 2011. Archeology and the debate on transition from reindeer hunting to pastoralism. Rangifer 31 (1): 111-127.

Swallow, Brent M., and Daniel W. Bromley. 1995. Institutions, governance and incentives on common property regimes for African rangelands. Environmental and Resource Economics 6: 99-118.

Wallerström, Thomas. 2018. Kunglig makt och samiska bosättningsmönster: Studier kring Väinö Tanners vinterbyteori. Oslo: Novus.

Open Access This chapter is licensed under the terms of the Creative Commons Attribution 4.0 International License (http://creativecommons.org/ licenses/by/4.0/), which permits use, sharing, adaptation, distribution and reproduction in any medium or format, as long as you give appropriate credit to the original author(s) and the source, provide a link to the Creative Commons license and indicate if changes were made.

The images or other third party material in this chapter are included in the chapter's Creative Commons license, unless indicated otherwise in a credit line to the material. If material is not included in the chapter's Creative Commons license and your intended use is not permitted by statutory regulation or exceeds the permitted use, you will need to obtain permission directly from the copyright holder.

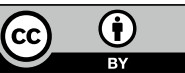

